Disclosure of Interests: Suzanne Arends Grant/research support from: Grant/ research support from Pfizer, Jolien F. van Nimwegen Consultant of: Bristol-Myers Squibb, Speakers bureau: Bristol-Myers Squibb, Gwenny M. Verstappen: None declared, Arjan Vissink: None declared, Neelanjana Ray Shareholder of: Bristol-Myers Squibb, Employee of: Bristol-Myers Squibb, Frans G.M. Kroese Grant/research support from: Unrestricted grant from Bristol-Myers Squibb, Consultant of: Consultant for Bristol-Myers Squibb, Speakers bureau: Speaker for Bristol-Myers Squibb, Roche and Janssen-Cilag, Hendrika Bootsma Grant/research support from: Unrestricted grants from Bristol-Myers Squibb and Roche, Consultant of: Consultant for Bristol-Myers Squibb, Roche, Novartis, Medimmune, Union Chimique Belge, Speakers bureau: Speaker for Bristol-Myers Squibb and Novartis.

DOI: 10.1136/annrheumdis-2020-eular.4500

\section{SAT0171 RITUXIMAB IN SYSTEMIC AUTOIMMUNE RHEUMATIC DISEASES: ONE CENTER EXPERIENCE OF TREATMENT 515 PATIENTS}

E. Nasonov ${ }^{1}$, T. Beketova ${ }^{1}$, L. P. Ananyeva ${ }^{1}$, S. Solovyev ${ }^{1}$, V. Vasiliev ${ }^{1}$, O. Koneva ${ }^{1}$, O. Desinova ${ }^{1}$, S. Palshina ${ }^{1}$, E. Sokol ${ }^{1}$, E. Nikollaeva ${ }^{1} .{ }^{1} V . A$. Nasonova Research Institute of Rheumatology, Moscow, Russian Federation

Background: B cells have important functions in the pathogenesis of systemic autoimmune rheumatic diseases (SARDs).

Objectives: The purpose of the research was to study the therapeutic option of Rituximab (RTM), a chimeric anti-CD20 antibody, in SARDs such as ANCA-associated systemic vasculitis (AAV), cryoglobulinemic vasculitis (CV), systemic lupus erythematosus (SLE), systemic sclerosis (SS), primary Sjögren syndrome (pSS) and IgG4-related disease (IgG4-RD).

Methods: We present data on efficacy and safety of RTM in 515 patients (pts) with SARDs. 103 pts had AAV (58- granulomatosis with polyangiitis, GPA; 35- microscopic polyangiitis, MPA and 10- eosinophilic granulomatosis with polyangiitis, EGPA), 21 pts had CV, 167- SLE, 90- SS, 100- pSS, 34- IgG4-RD. Characteristics of pts and results of RTM treatment are present in Table. Mean follow-up duration after initiation of RTM was 25- 58 months.

Results: The average cumulative RTM dose in all groups exceeded $2.4 \mathrm{~g}, 71 \%$ of pts received repeated RTM courses $(0.5-1.0 \mathrm{~g})$ every $4-12$ months. Complete (good) clinical response was achieved in $70-93 \%$ pts, except for the SLE (49\%complete response, 32- incomplete and 19\%- no response). Usage of repeated RTM courses increased the clinical efficacy and reduced the risk of recurrence. Despite the fact that the study population included a high percentage of pts with severe or refractory SARDs, total mortality rate was about $6 \%$ during the follow-up period, highest in CV and AAV (14-11\%). In AAV and SLE infections constitute a significant proportion of serious adverse reactions (10-11\%). Late-onset neutropenia was only in pts with AAV (12\%) and SLE (3\%).

Conclusion: Treatment with RTM was highly effective in SARDs. In certain SARDs RTM safety profile of should be considered during treatment planning. Further studies of the targeted anti-B-cell therapy, including RTM efficacy and safety in SARDs, clarification of the indications and optimal RTM regimens are needed.

Table.

\begin{tabular}{|c|c|c|c|c|c|c|c|}
\hline \multirow[t]{2}{*}{ Parameters } & \multicolumn{2}{|c|}{ AAV } & \multirow[t]{2}{*}{ CV } & \multirow[t]{2}{*}{ SLE } & \multirow[t]{2}{*}{ ss } & \multirow[t]{2}{*}{ pss } & \multirow[t]{2}{*}{ IgG4-RD } \\
\hline & $\begin{array}{l}\text { GPA, } \\
\text { MPA }\end{array}$ & EGPA & & & & & \\
\hline $\mathrm{N}$ pts & 93 & 10 & 21 & 167 & 90 & 100 & 34 \\
\hline Age, years & $\begin{array}{c}41 \\
(16-67)\end{array}$ & $\begin{array}{c}50 \\
(24-71)\end{array}$ & $53,6+29$ & $\begin{array}{c}41 \\
(18-52)\end{array}$ & $\begin{array}{c}47 \\
(17-71)\end{array}$ & $42+12,24$ & $247,4+15,9$ \\
\hline Percentage of females & $56 \%$ & $90 \%$ & $52 \%$ & $92 \%$ & $75 \%$ & $97 \%$ & $60 \%$ \\
\hline Duration of disease, months ${ }^{*}$ & $\begin{array}{c}14 \\
(1-288)\end{array}$ & $\begin{array}{c}11 \\
(1-180)\end{array}$ & $\begin{array}{c}72 \\
(3-96)\end{array}$ & $\begin{array}{c}18 \\
(2-47)\end{array}$ & $\begin{array}{c}70 \\
(7-264)\end{array}$ & $\begin{array}{c}90 \\
(36-168)\end{array}$ & $\begin{array}{c}24 \\
(6-60)\end{array}$ \\
\hline Cumulative RTM dose, $\mathrm{g}^{*}$ & $3(0,5-8)$ & $\begin{array}{c}3 \\
(1,5-5,5)\end{array}$ & $4,7+3,8$ & $\begin{array}{c}2,4 \\
(1,8 \pm 0,8)\end{array}$ & $\begin{array}{c}2,9 \\
(0,5-6)\end{array}$ & $5,5+1,5$ & $4+1,5$ \\
\hline $\begin{array}{l}\text { Follow-up duration after the } \\
\text { first RTM course, month* } \\
\text { Clinical response, \% }\end{array}$ & $\begin{array}{c}37 \\
(1-96)\end{array}$ & $\begin{array}{c}36 \\
(14-94)\end{array}$ & $\begin{array}{c}52 \\
(6-108)\end{array}$ & $\begin{array}{c}38 \\
(12-67)\end{array}$ & $\begin{array}{c}27 \\
(12-42)\end{array}$ & $\begin{array}{c}58 \\
(24-96)\end{array}$ & $\begin{array}{c}25 \\
(3-60)\end{array}$ \\
\hline Complete (good) & $93 \%$ & $90 \%$ & $71 \%$ & $49 \%$ & $70 \%$ & $92,5 \%$ & $77 \%$ \\
\hline Incomplete response & $6 \%$ & $10 \%$ & $29 \%$ & $32 \%$ & $24 \%$ & $6,5 \%$ & $23 \%$ \\
\hline No response & $1 \%$ & $0 \%$ & - & $19 \%$ & $6 \%$ & $1 \%$ & - \\
\hline $\begin{array}{l}\text { Relapse } \\
\text { Glucocorticoids dose, mg/ } \\
\text { day*: }\end{array}$ & $8 \%$ & $30 \%$ & - & - & nd & - & - \\
\hline Before RTM & $30(5-60)$ & $20(7,5-50)$ & $4,4(0-24)$ & $28(15-40)$ & ) $12(0-$ & $7,5(0-40) 1$ & $10(2,5-40)$ \\
\hline After RTM & $5(0-10)$ & $7,5(5-10)$ & $1,5(0-4)$ & $7,5(5-15)$ & $\begin{array}{c}25) \\
9(0-15)\end{array}$ & 1,25 & 0,5 \\
\hline Immunosuppressants & & & & & & & \\
\hline$\%$ pts before RTM & $72 \%$ & $90 \%$ & $38 \%$ & $65 \%$ & $43 \%$ & $44 \%$ & $40 \%$ \\
\hline$\%$ pts after RTM & $43 \%$ & $70 \%$ & $5 \%$ & $46 \%$ & $50 \%$ & $8 \%$ & $10 \%$ \\
\hline Infusion-related reactions, & $9 \%$ & $20 \%$ & $24 \%$ & $4 \%$ & $2 \%$ & $10 \%$ & $3 \%$ \\
\hline
\end{tabular}

Table.

\begin{tabular}{|c|c|c|c|c|c|c|c|}
\hline \multirow[t]{2}{*}{ Parameters } & \multicolumn{2}{|c|}{ AAV } & \multirow[t]{2}{*}{ cV } & \multirow[t]{2}{*}{ SLE } & \multirow[t]{2}{*}{ ss } & \multirow[t]{2}{*}{ pSS } & \multirow[t]{2}{*}{ IgG4-RD } \\
\hline & $\begin{array}{l}\text { GPA, } \\
\text { MPA }\end{array}$ & EGPA & & & & & \\
\hline $\mathrm{N}$ pts & 93 & 10 & 21 & 167 & 90 & 100 & 34 \\
\hline $\begin{array}{l}\text { Pts with serious adverse } \\
\text { reactions, }\end{array}$ & $26 \%$ & $40 \%$ & $5 \%$ & $14 \%$ & $2 \%$ & $5 \%$ & $3 \%$ \\
\hline $\begin{array}{l}\text { including: infections, } \\
\text { neutropenia }\end{array}$ & $\begin{array}{l}11 \% \\
10 \%\end{array}$ & $\begin{array}{l}10 \% \\
20 \%\end{array}$ & - & $\begin{array}{l}10 \% \\
3 \%\end{array}$ & $2 \%$ & $5 \%$ & $3 \%$ \\
\hline $\begin{array}{l}\text { Deceased pts during the } \\
\text { follow-up }\end{array}$ & $11 \%$ & - & $14 \%$ & $5 \%$ & $6 \%$ & $2 \%$ & - \\
\hline
\end{tabular}

*Data are provided in the following format: median \& min-max range in the brackets

Disclosure of Interests: None declared

DOI: 10.1136/annrheumdis-2020-eular.2142

\begin{tabular}{|l|l}
\hline SAT0172 & UTILIZATION OF HYDROXYCHLOROQUINE AND \\
CORTICOSTEROIDS AMONG LUPUS PATIENTS WITH \\
INCIDENT END-STAGE RENAL DISEASE (ESRD) ONSET: \\
A LONGITUDINAL STUDY USING USRDS REGISTRY
\end{tabular}

A. R. Broder ${ }^{1}$, W. Mowrey ${ }^{2}$, A. Valle ${ }^{3}$, B. Goilav ${ }^{4}$, K. Yoshida ${ }^{5}$, K. Costenbader ${ }^{5}$. ${ }^{1}$ Montefiore/Einstein, Medicine/Rheumatology, Bronx, United States of America; ${ }^{2}$ Einstein, Bronx, United States of America; ${ }^{3}$ Montefiore, Bronx, United States of America; ${ }^{4}$ Montefiore, Btonx, United States of America; ${ }^{5}$ Harvard, Boston, United States of America

Background: The development of ESRD due to lupus nephritis is one of the most common and serious complications of SLE. Mortality among SLE ESRD patients is 4-fold higher compared to lupus nephritis patients with preserved renal function ${ }^{1}$ Mortality in SLE ESRD is also twice as high compared with non-SLE ESRD, even though SLE patients develop ESRD at a significantly younger age. In the absence of ESRD specific guidelines, medication utilization in SLE ESRD is unknown.

Objectives: The objective of this study was to investigate the real-world current US-wide patterns of medication prescribing among lupus nephritis patients with new onset ESRD enrolled in the United States Renal Disease Systems (USRDS) registry. We specifically focused on $\mathrm{HCQ}$ and corticosteroids (CS) as the most used medications to treat SLE.

Methods: Inclusion: USRDS patients 18 years and above with SLE as a primary cause of ESRD (International Classification of Diseases, $9^{\text {th }}$ Revision (ICD9) diagnostic code 710.0, previously validated ${ }^{2}$ ). who developed ESRD between January 1st, 2006 and July 31, 2011 (to ensure at least 6 months of follow-up in the USRDS). Patients had to be enrolled in Medicare Part D (to capture pharmacy claims). The last follow-up date was defined as either the last date of continuous part D coverage or the end of the study period, Dec 31, 2013.

Results: Of the 2579 patients included, 1708 (66\%) were HCQ- at baseline, and $871(34 \%)$ were $\mathrm{HCQ}+$ at baseline. $\mathrm{HCQ}+$ patients at baseline had a slightly lower duration of follow-up compared to HCQ- patients at baseline, median (IQR) of $2.32(1.33,3.97)$ years and $2.55(1.44,4.25)$ years, respectively, $p=0.02$. During follow-up period, only 778 (30\%) continued $\mathrm{HCQ}$ either intermittently or continuously to the last follow-up date, 1306 (51\%) were never prescribed HCQ after baseline, and 495 (19\%) discontinued HCQ before the last follow-up date. Of the 1801 patients who were either never prescribed or discontinued HCQ early after ESRD onset, 713 (40\%) were prescribed CS to the end of the follow-up period: $55 \%$ were receiving a low dose $<10 \mathrm{mg} /$ daily, and 43 were receiving moderate dose (10-20mg daily)

Conclusion: $\mathrm{HCQ}$ may be underprescribed and CS may be overprescribed in SLE ESRD. Changing the current prescribing practices may improve outcomes in SLE ESRD

References:

[1] Yap DY et al., NDT 2012.

[2] Broder A et al., AC\&R 2016.

Acknowledgments : The data reported here have been supplied by the United States Renal Data System (USRDS). The interpretation and reporting of these data are the responsibility of the author(s) and in no way should be seen as an official policy or interpretation of the U.S. government.

Funding: : NIH/NIAMS K23 AR068441 (A Broder), NIH/NIAMS R01 AR 057327 and K24 AR 066109 (KH Costenbader)

Disclosure of Interests: : Anna R. Broder: None declared, Wenzhu Mowrey: None declared, Anna Valle: None declared, Beatrice Goilav: None declared, Kazuki Yoshida: None declared, Karen Costenbader Grant/research support from: Merck, Consultant of: Astra-Zeneca

DOI: 10.1136/annrheumdis-2020-eular.5103 